Auch wenn es gerade bei der Bekämpfung kriminalisierter Gewaltökonomien lange Zeit zu schwerwiegenden Versäumnissen kam, haben die VN doch bereits gezeigt, dass sie durchaus das Potential haben, auf die Herausforderungen der »neuen « Kriege zu reagieren. So haben sie zum Beispiel darauf gedrängt, in der Demokratischen Republik Kongo eine sehr breite Übergangsregierung zu bilden, damit die zahlreichen Konfliktparteien Repräsentanten entsenden können. Des Weiteren haben sie nach der Beendigung des Bürgerkriegs in Sierra Leone, der durch hemmungslose Gewalt gegen die Zivilbevölkerung gekennzeichnet war, die Einrichtung eines Tribunals und einer Wahrheits- und Versöhnungskommission maßgeblich vorangetrieben. Darüber hinaus haben die VN seit den späten 1990er Jahren auch ihre Instrumente zur Schwächung kriminalisierter Gewaltökonomien verbessert, etwa indem sie Sanktionen auch gegen private Akteure zur Unterbindung des Schmuggels mit so genannten Konfliktressourcen (»smart and targeted sanctions «) verhängt und zunehmend auch durchgesetzt sowie die von der Privatwirtschaft initiierte Entwicklung und Umsetzung eines Herkunftszertifikatsregimes für den Handel mit Rohdiamanten (Kimberley Prozess) unterstützt haben.

Diese Teilerfolge der VN-Bemühungen zur Friedenskonsolidierung sollten aber nicht über den unvollständigen und oft unkoordinierten und deshalb beschränkt wirksamen Charakter dieser Instrumente hinwegtäuschen. Es stellt sich deshalb die
Frage nach den Chancen, ob die VN derartige Instrumente weiterentwickelt und in Zukunft vermehrt und zielführend einsetzen kann. Die Einrichtung der Peacebuilding-Kommission, die von der VN-Generalversammlung im September 2005 beschlossen wurde, um Defizite vor allem im Bereich der Friedenskonsolidierung zu überwinden, mag Anlass zu einer positiven Einschätzung geben. Denn die Kommission soll nicht nur Peacebuilding-Prozesse über die kurze Aufmerksamkeitsspanne des Sicherheitsrats hinaus begleiten und überwachen, sondern darüber hinaus die Mobilisierung von Ressourcen erleichtern und zur Überwindung der Kohärenzund Koordinationsprobleme zwischen den zahlreichen beteiligten Institutionen beitragen. ${ }^{27}$ Freilich wird der Erfolg der Peacebuilding-Kommission maßgeblich davon abhängen, ob sie die Unterstützung der VN-Mitgliedstaaten gewinnen wird. Sollte es den Vereinten Nationen aber tatsächlich mit Rückendeckung der Mitgliedstaaten gelingen, ihre logistischen Kapazitäten zu verbessern und zugleich ihre Strategien und Instrumente weiterzuentwickeln, dann besteht durchaus die Chance, dass sie in den kommenden Jahren auch Herausforderungen wie der Stabilisierung von Friedensprozessen nach »neuen« Kriegen angemessen begegnen und dadurch Rückfällen in Konflikte vorbeugen können.

27 Vgl. Beitrag von Ulrich Schneckener und Silke Weinlich in diesem Heft.

\title{
Challenges of Peacebuilding: The Example of Kosovo
}

\section{Søren Jessen-Petersen*}

\begin{abstract}
This article provides an overview of the role of the United Nations Interim Administration Mission in Kosovo (UNMIK) and its progress in fulfilling its mandate, including the facilitation of a process leading to a settlement of Kosovo's status. It then examines some of the challenges remaining for the mission as the status talks get underway and ends by providing some observations on lessons identified from the mission that may be of relevance in other peacekeeping or peacebuilding missions.
\end{abstract}

Keywords: UNMIK, Kosovo, Western Balkans, peacekeeping, peacebuilding, security

\section{Introduction ${ }^{2}$}

$\mathrm{O}$ n 24 October 2005, the Security Council issued a Presidential Statement inviting the Secretary General to initiate the process that will, over the coming months, culminate in a decision on Kosovo's future status. So begins the end of the United Nations Interim Administration Mission in Kosovo (UNMIK). Whatever results from this process will supersede Security Council Resolution 1244 (1999) and with it the mandate of a mission that has so far assisted Kosovo for almost six-and-a-half years.

\footnotetext{
* Søren Jessen-Petersen is Special Representative of the UN Secretary General and Head of the United Nations Interim Administration Mission in Kosovo (UNMIK).

2 This article was written in early November 2005.
}

Kosovo's history - of increasing oppression in the 1990s, mirrored by the development of "parallel institutions « by the Kosovo Albanian minority - is of course unique. Its short war was particularly bloody and traumatic and NATO's initial intervention both more protracted and more determined that the respective sides had thought it would be. In the words of the well-known commentator and journalist Tim Judah, war was swiftly followed by revenge, as if to reinforce the divisions between Kosovo's two main ethnic groups. It is this legacy - of war, revenge, mistrust and opacity - that UNMIK has been dealing with for the past few years. Many of the problems which now confront us are only fully resolvable in the context of a status settlement. But on some of these and others we can anticipate progress over the coming months in parallel with, but separate from, that broader political debate. 


\section{Mandate}

UNMIK was established in 1999 with the following broad mandate:

- Promoting the establishment, pending a final settlement, of substantial autonomy and self-government in Kosovo;

- Performing basic civilian administrative functions where and for as long as required;

- Organising and overseeing the development of provisional institutions for democratic and autonomous self-government pending a political settlement, including the holding of elections;

- Transferring, as these institutions are established, its administrative responsibilities while overseeing and supporting the consolidation of Kosovo's local provisional institutions and other peacebuilding activities;

- Facilitating a political process designed to determine Kosovo's future status;

- In a final stage, overseeing the transfer of authority from Kosovo's provisional institutions to institutions established under a political settlement;

- Supporting the reconstruction of key infrastructure and other economic reconstruction;

- Supporting, in coordination with international humanitarian organizations, humanitarian and disaster relief aid;

- Maintaining civil law and order, including establishing local police forces and in the interim through the deployment of international police personnel to serve in Kosovo;

- Protecting and promoting human rights;

- Assuring the safe and unimpeded return of all refugees and displaced persons to their homes in Kosovo.

Some of these mandated tasks were relatively short-term in nature and much of the humanitarian and rebuilding work of the mission was completed much more quickly after the establishment of the mission than anticipated.

\section{Establishment of local institutions}

The establishment of the Provisional Institutions of Self-Government (PISG) and the gradual, and continuing transfer of competencies to them, has been ongoing now since the promulgation of the Constitutional Framework in 2001. Since the establishment of the mission there have been four elections in Kosovo, each one being better conducted than the last as according to the assessments made by intensive international monitoring missions.

The establishment of democratically-elected and accountable institutions was an entirely new occurrence in Kosovo. As a result of its success so far, the Civil Administration »Pillar « of UNMIK has in the past weeks been downgraded to the status of a Department in the office of the Special Representative of the Secretary General. At the same time regional civil administration offices have begun to close down across Kosovo. The oversight role will of course continue, as mandated under
UNSCR 1244, but for most purposes the executive authority provided by that Resolution is now fully exercised by local institutions.

Sustainable peacebuilding requires local ownership; the PISG proved exactly that. They would undoubtedly be even more effective in reflecting the view of all those who live in Kosovo if more Kosovo Serb politicians felt able to work within them. Joining the Assembly, where, despite a regrettable electoral boycott in October 2004, the Serbs have ten reserved seats, would be a first step. It is therefore disappointing that despite several approaches and requests from senior Kosovo Serb politicians, the UN Security Council and many others, Belgrade has repeatedly failed to give its consent for the main Kosovo Serb political parties to join the legislative body that has the most impact in shaping their lives. We are in a process of trying to shape the future of the society in Kosovo. It is absolutely essential that those persons who have the most direct interest in shaping their own future be given a chance to participate in the political process.

\section{Civil Law and Order}

The establishment of efficient, multi-ethnic, trusted organs of law enforcement in Kosovo was always going to be an uphill struggle. For ethnic Albanians the police had, at least in the recent past, represented a repressive and, to them, alien regime. For their part Kosovo Serbs were unwilling to trust an overwhelmingly ethnic Albanian force to protect their interests and rights. As UNMIK's mandate makes clear, this circle was originally squared in Kosovo by the deployment of a large international police force under the UNMIK flag.

At its peak in December 2000, the UNMIK Police (UNMIK-P) had 3, 505 officers, but maintaining such a large international force was neither sustainable nor desirable. An international presence cannot provide the kind of localised community policing which is necessary in a society such as Kosovo. Moreover, with high personnel turnover rates and short contracts, and therefore a sometimes short-term institutional memory, the international police presence has not been able to get to grips with more entrenched and difficult forms of criminal activity as we would have liked - though this has, I believe, begun to change in recent years as longer-serving international officers have risen within the system and as specialised units have been set up to tackle organised crime, corruption and other specific areas of criminal activity.

Policing clearly, for the most part, must ultimately be a locally owned and locally managed affair. So under the tutelage of UNMIK-P, and with training provided by the OSCE-mandated police training college in Vushtrri/Vucitrn, UNMIK built up the Kosovo Police Service - an entirely new force, constructed from scratch since September 1999. The KPS now consists of some 6,530 officers, deployed throughout Kosovo, and has taken operational command of all police stations in Kosovo and of all police regions with the exception of Mitrovicë/ Mitrovica. 
The KPS is, I believe, one of UNMIK's greatest successes. Of the 991 officers, 15.2 per cent are from minority groups, including 608 Kosovo Serbs, forming 9.3 per cent of the total force. Multi-ethnic patrols are routine in ethnically-mixed areas and in opinion polls the KPS emerges as one of the most trusted local institutions, with rates of satisfaction in its performance running between 80 per cent and 90 per cent, according to polling by Riinvest. This rate of satisfaction is only equalled by KFOR.

However, despite its successes, the KPS is not a perfect institution. Too many high-profile crimes go unsolved, particularly in the fields of organised crime and corruption. For these reasons there is continuing discussion about the extent to which some degree of international executive authority might be required in some limited fields of policing after the end of the UNMIK mandate. Who would exercise any such authority is not clear at present, though with its regional experience of rule of law missions, and its close interest in the development of the region, the European Union would seem to be the likeliest candidate.

In any case, the police are not the only institution required for the establishment of the rule of law. A functioning judiciary is also necessary. As with policing, UNMIK has followed a twin-track approach in the judiciary by using international judges and prosecutors while building up the capacities of local counterparts and handing increasing responsibility to them. There are currently 397 local judges and prosecutors working in Kosovo. Thirty-eight of them (i.e. 9.6 per cent) are from ethnic minorities, including 15 Serbs (representing 3.8 per cent of the total). As with the police, concerns arise in terms of the judiciary's performance with respect to the most sensitive crimes and, again in common with policing, there is an ongoing discussion about the need for a continuing executive role for the international community in this field after the final status of Kosovo is determined.

UNMIK's policy over the past few years has been to devolve as much authority as is possible under UNSCR 1244 to the local institutions established under that resolution. In the case of police and justice we have reached the end of what can be devolved without the establishment of ministries to manage the new responsibilities. The creation of Ministries of Public Order and Justice is therefore planned for the end of this year.

\section{Returns}

Returns is an area where performance has not been so quite so rosy. The number of returning displaced persons remains disappointing, and we would all like to see the process accelerated significantly. However, the returns process should not be judged primarily on the number of people who choose to return, but rather on creating the conditions that will allow a displaced person to exercise a free choice as to whether to return or not.

First and foremost, returnees have got to have a sense of security, which must include the ability to move around freely. Secondly, they must have clear property rights and ready ac- cess to that property. Finally, they must have economic opportunities to make their return sustainable in the mid- and long term. These conditions are clearly inter-related and improvements have been made on all fronts, despite an occasional lack of momentum on the PISG side and also, at times, an ambiguous commitment to the returns process from certain quarters in Belgrade.

In terms of property rights and the access to property issue, good progress has been seen in recent times. However this progress has followed on from a long period of inaction and the work in this sector is still only nascent. Thankfully, the institutions are now working much better to deal with property disputes. Belgrade has a useful role to play in this respect by handing back to Kosovo the relevant cadastral records, which were removed from Kosovo in 1999, so that ownership and occupation of property can be ascertained more quickly.

The economic sphere has been improving slowly, but from a very low base level. In the end we should not be naïve in our expectations of the economic prospects for returnees unless there is a significant improvement in the overall economic conditions of Kosovo and we cannot realistically expect to see any economic take off in Kosovo until after the status question has been settled.

Freedom of movement remains a touchstone by which to measure returnees' conditions. The best measure of this is straw polling evidence provided by the KPS, using a sample of 434 minority representatives throughout Kosovo. The most recent figures, produced in October 2005, indicate that 85 per cent of respondents had travelled outside their place of residence within Kosovo and that 65 per cent of those asked felt that they could travel safely - this figure regrettably coming down from 70 per cent in June. In the same survey 59 per cent of respondents indicated that they drove in their own vehicles, walked or took public transport when travelling in Kosovo; 12 per cent used UN bus services; 6 per cent travelled by unspecified »other means «. As indicated above, 15 per cent did not travel at all. This leaves 8 per cent travelling with police or KFOR escorts.

By any measure 8 per cent is too high a figure. No one should be satisfied until minority communities and their religious buildings no longer require protection as a matter of routine. But it is important that the figures be remembered. The image of minorities in Kosovo is all too often one of beleaguered groups beset by implacable enemies. The figures cited do not bear this out.

\section{The status process}

In the end, real movement on returns - as on so many other issues - is likely to have to await an outcome from the status process. As will be seen from the mandate elements of UNSCR 1244 cited above facilitating a political process designed to determine Kosovo's future status" has been part of UNMIK's role from the beginning. But in reality this part of the mandate was in abeyance for the larger part of UNMIK's history. It has only been in the past year that a consensus has developed 
on the need for Kosovo's status to be addressed. The first step in this process took place in May this year, with a positive assessment by UNMIK of Kosovo's progress in implementing the »Standards «. This positive assessment was endorsed by the Security Council. There followed the appointment of Ambassador Kai Eide to undertake a comprehensive review of the situation in Kosovo. It was his positive review, endorsed by the Secretary General, which resulted in the Security Council's decision in October to recommend the opening of status talks.

The »Standards « referred to above were formally rolled out in December 2003 (though they had a long pre-history before this date). They were widely misunderstood at the time as a series of hoops through which the PISG were expected to jump before the issue of status talks could be considered. In fact the standards provide a framework for both UNMIK and the PISG in defining targets in key policy reform areas, particularly those related to minority rights, and can therefore be compared to the kind of transitional reform frameworks recommended by the EU and others elsewhere in the Western Balkans and in similar regions in transition. The benchmarking of standards has allowed for the monitoring of rates of progress in any given area, and a »traffic light « system has allowed us to flag areas of concern to the PISG as soon as they come to our attention. In this way UNMIK has assisted the PISG in achieving progress in standards implementation and thereby helped it reach the point at which status talks can begin.

At the same time, UNMIK also played a role in attempting to bring the main Kosovo political parties and their leaders together to begin to prepare for these talks. Through the »Kosovo Forum « preliminary discussions were held in the summer of 2005, though preparations have only begun in earnest since the formation of President Rugova's »Team of Unity«, including the Prime Minister, the Speaker of the Kosovo Assembly and the leaders of Kosovo's two largest opposition parties, in the autumn.

The resolution of Kosovo's status has now become imperative from a number of perspectives. The uncertainty inherent in the status quo undermines potential reconciliation between the two main ethnic groups in Kosovo, who have opposing views on what its future should be. It also taints regional politics and makes difficult any meaningful dialogue between Belgrade and Prishtinë/Priština on practical issues such as return. Finally, and perhaps most importantly from the point of view of Kosovo's population, it perpetuates economic uncertainties, which prevent Kosovo from accessing the international financial institutions and capital markets, and deters largescale investment.

\section{Challenges ahead}

Yet while the status process is vital, in terms of providing solutions to the most intractable problems in Kosovo, it will not bring an end to normal politics in Kosovo, or to the work of UNMIK. We have identified six priority areas for the mission over the coming six to twelve months.
The first is to continue apace with the implementation of standards. We are in the process of reviewing the Kosovo Standards Implementation Plan to ensure maximum focus on actions which will do most to improve the living conditions of minorities in Kosovo and thereby to promote a multi-ethnic future. In pursuit of this goal we are now in the final stages of establishing a wholly independent Human Rights Advisory Panel whose members will be nominated by experts including the President of the European Court of Human Rights.

Secondly we will be pursuing aggressively a comprehensive reform of local government in Kosovo. Decentralisation has been identified as one of the key ways to ensure both maximum influence over local events for all voters, and maximum engagement in political life from Kosovo's minorities. While continuing to work on a number of "pilot projects « around Kosovo, we will also work with the PISG to increase dialogue with Belgrade in order to ensure that the government there is able to inject its thoughts into the debate on a future comprehensive reform of local government in Kosovo.

Thirdly, we will continue to pursue a comprehensive security agenda. This will of course include the gradual and phased transfer of competencies from UNMIK to the two new ministries of public order and justice, which has been mentioned already. We will also be looking beyond the immediate requirements of these two ministries by pushing forward a comprehensive Internal Security Sector Review. This process, which will include dialogue with all communities in Kosovo, is intended to help formulate a sense of the challenges which face Kosovo in the security field and thereby to assist in the design of its future internal security architecture.

Fourthly, we will refocus our efforts in the field of capacity building in order to ensure that, regardless of the outcome of the status talks, Kosovo's institutions will be fully capable of taking on the responsibilities that flow to them.

Fifthly, we will continue to restructure the mission throughout the coming period with a view to maintaining maximum efficiency from the available resources while co-operating with our international partners on a phased transition to any successor arrangements after the end of status talks. We have begun a process of internal dialogue with key partners to identify those areas where there are gaps and overlaps in the international presence. This is the first step towards defining our future roles and resource requirements.

Finally, we will continue to provide the fullest possible support to KFOR in its efforts to ensure the maintenance of a safe and secure environment for everyone in Kosovo. The security situation is, I believe, as good now as it has ever been since 1999. Clearly tensions lie only beneath the surface - as a series of recent small-scale attacks on UNMIK and on local Serbs indicates. Given the particularly sensitive stage we are now entering, in terms of the opening of talks, that fragile surface could easily be scratched. Threats to security could come from several different quarters, depending on the course of events. We keep a close eye on all security indicators and allow no room for complacency. UNMIK and KFOR maintain an extremely high level of co-operation, and NATO's recent reorganisation of its internal structures should allow it to re- 
spond forcefully and flexibly to any serious security threat which might develop.

\section{Status - the need for clarity}

UNMIK has been an unusual UN peacekeeping mission, not least in as much as peacekeeping duties as such have not been carried out by the United Nations, but rather by NATO, in the form of KFOR.

In addition, and despite its broad mandate, UNMIK was not tasked with addressing the true root causes of the 1998-99 conflict, or of the years of oppression and separation that had preceded it. Instead, UNSCR 1244 put off the question of status resolution to a later date - a date that we have now reached.

It is not for UNMIK to have any view on what the outcome of the status talks should be, except to state the well-known, and very welcome, principles enunciated by the EU, the US, and indeed the Contact Group as a whole: these principles, to guide the talks on status, are that there be no partition of Kosovo; that there be no new union with any neighbouring country; and that there be no return to the situation prevailing before March 1999. It is clear that in any resolution of status the full protection of minority rights, the resolution of property issues, the clear right of return, and the protection of cultural and religious heritage must be addressed as a base-line among many other important issues.

Status is not only a peacebuilding problem in Kosovo, it is the peacebuilding problem in Kosovo. So far the work of the international community in Kosovo has been somewhat akin to building a house from the roof downwards. We now have a fine roof and good walls in place - democratic institutions, multi-ethnic policing, legal protection of minority rights, etc. But in the absence of foundations - a fundamental legal basis for the continuation of these laws and institutions into the future - the work is, and will remain, incomplete.

With the beginning of status talks we have reached those foundations. This must be regarded as the true beginning of the end of the peacebuilding process in Kosovo and in the wider region.

\section{Some lessons?}

Looking at Kosovo for lessons which might be applied elsewhere, it is apparent how different Kosovo is from other scen- arios than how similar. However, three potential lessons do stand out:

The UNMIK Pillar structure: UNMIK has from the beginning been a co-operative venture. Its structure incorporates two other regional organisations - the OSCE and the EU - as two of three (formerly four) pillars. On the whole, and despite teething problems, this arrangement has worked well and could be replicated elsewhere as a means of ensuring the representation and full involvement of regional organisations in UN missions, or of UN structures in regional organisation-led missions.

The economy: It should go without saying - and too often does - that the economy lies at the heart of resolving political problems. Kosovo's economy is unusually problematic - with unemployment above 50 per cent and a young population. While economic reconstruction was part of UNMIK's mandate, there was little beyond this to guide the mission in terms of privatisation and other essential measures to allow the economy to begin to function normally - or as normally as it could in the absence of a status settlement. UNMIK has indeed pushed these processes forward, but it has been a slow process and one constantly challenged. Though future missions are unlikely ever to have to contend with the same sorts of problems as UNMIK it is important that, where interim administration is part of a mission's function, the economy is a prioritised part of their mandates, with proper provision for hiring the sort of expertise that this requires.

Local ownership: The handover of competencies to local ownership has been one of UNMIK's greatest successes. The mission could not exercise executive authority in all key areas indefinitely, so some transfer of competencies was inevitable. Though what was important was to keep the transfers flowing, mainly in order to ensure local responsibility for issues, but partly also to maintain the sense of momentum - of a political process heading to a conclusion, which was otherwise lacking in the absence of any obvious build-up to status talks.

Ideally these, and other more insightful lessons, will be drawn together as UNMIK prepares to close shop in Kosovo. We now have a clear set of priorities and a reasonably clear timetable - in the latter case for the first time. We must attempt to build into the mission's last stages a stock-taking exercise which will allow us to examine what policies and structures worked best and how these can be applied beyond the mission area. Any such exercise should be honestly undertaken and honestly presented and the results should be publicly available so that any lessons identified within them can be learned for the future. 